\title{
Tingkat Kompetensi Teknis Petani dalam Berusahatani Singkong (Kasus Kelompok Mekar Tani Desa Cibanteng Kecamatan Ciampea Kabupaten Bogor
}

\author{
Ture Simamora ${ }^{\mathrm{a}}$, Renfred Luik ${ }^{\mathrm{b}}$ \\ ${ }^{a}$ Fakultas Pertanian, Universitas Timor, Kefamenanu, TTU - NTT, Indonesia. Email : feathertures@ rocketmail.com \\ ${ }^{b}$ Sekolah Pascasarjana, Institut Pertanian Bogor, Bogor - Jawa Barat, Indonesia. Email : Renfred291190@gmail.com
}

\section{Article Info}

Article history:

Received 8 Agustus 2019

Received in revised form 25 Agustus 2019

Accepted 10 September 2019

DOI:

Keywords:

Hubungan

Karakteristik

Kompetensi

Singkong https://doi.org/10.32938/ag.v4i4.824

\begin{abstract}
Abstrak
Kompetensi adalah karakteristik seseorang terkait dengan kinerja terbaik dalam pekerjaan tertentu. Kompetensi petani tidak sa ma antara satu petani dengan petani lainnya, hal ini terkait dukungan karakteristik yang dimiliki oleh petani. Kelompok Mekar Tani Desa Cibanteng masih berusahatani singkong dengan cara tradisional. Penelitian bertujuan untuk menganalisis karakteristik petani singkong, menganalisis kompetensi teknis usahatani singkong, dan menganalisis hubungan antara karakteristik petani dengan kompetensi teknis. Hasil penelitian menunjukkan sebanyak 63.30 persen petani singkong telah berumur tua, 53.30 persen berpendidikan formal rendah, 60 persen petani memiliki pengalaman berusahatani singkong rendah, 80 persen petani memiliki luas lahan sempit, 93.33 persen petani memiliki motivasi tinggi dalam berusahatani, dan 36.67 persen dukungan sarana dan prasarana produksi tinggi. Kompetensi teknis petani rendah dalam berusahatani singkong. Kompetensi teknis petani dalam berusahatani singkong. Pengetahuan petani tinggi dalam berusahatani. Sikap petani tinggi dalam berusahatani singkong. Keterampilan petani rendah dalam berusahatani singkong. Karakteristik petani singkong yang menunjukkan hubungan nyata dengan kompetensi teknis dalam berusahatani singkong meliputi pengalaman berusahatani, luas lahan dan dukungan sarana prasarana produksi. Dengan demikian untuk mengembangkan kompetensi teknis petani diperlukan peningkatan pelayanan penyuluhan di bidang pertanian singkong.
\end{abstract}

\section{Pendahuluan}

Kompetensi teknis usaha adalah wujud perilaku pelaku usaha dalam merencanakan serangkaian aktivitas untuk mencapai target produksi (Bakhtiar et. al 2017). Kompetensi teknis usahatani merujuk pada kemampuan petani dalam melakukan aktivitas atau kegiatan pertaniannya secara mandiri (Leasa $e$ al. 2018). Kompetensi teknis usahatani meliputi persiapan lahan, pemilihan bibit tanaman, pengendalian hama dan penyakit, panen, serta penanganan pascapanen. Kompetensi teknis memiliki keterkaitan dengan karakteristik petani sebagai pelaku utama dalam usahatani. Karakteristik petani meliputi umur, tingkat pendidikan, pengalaman luas lahan, tanggungan keluarga dan motivasi. Kompetensi petani tidak sama antara satu petani dengan petani lainnya, hal ini terkait dukungan karakteristik yang dimiliki oleh petani.

Dewi et. al (2018) mengemukakan pembangunan pertanian harus didukung oleh karakteristik petani sebagai pelaku utama. Manyamsari dan Mujiburrahmad (2014) mengemukakan karakteristik petani memiliki hubungan dengan kompetensi teknis yang dimiliki petani itu sendiri. Kelompok Mekar Tani Desa Cibanteng, Kecamatan Ciampea, Kabupaten Bogor merupakan salah satu kelompok tani binaan UPT Pertanian Cibungbulang. Petani pada kelompok tersebut masih berusahatani singkong dengan cara tradisional. Petani diduga belum mengadopsi inovasi dalam berusahatani singkong. Padahal luas lahan pertanian semakin berkurang.

Perilaku bertani yang masih tradisional diduga terkait hubungan karakteristik petani dengan kompetensi teknis berusahatani singkong pada Kelompok Mekar Tani. Berdasarkan uraian latar belakang, maka penelitian ini bertujuan untuk (1) Menganalisis karakteristik petani singkong pada Kelompok Mekar Tani Desa Cibanteng, Kecamatan Ciampea, Kabupaten Bogor 2) menganalisis kompetensi teknis usahatani singkong pada Kelompok Mekar Tani Desa Cibanteng, Kecamatan Ciampea, Kabupaten Bogor (3) menganalisis hubungan antara karakteristik petani dengan kompetensi teknis usahatan singkong pada Kelompok Mekar Tani Desa Cibanteng, Kecamatan Ciampea, Kabupaten Bogor.

\section{Metode}

Penelitian dilakukan dengan menggunakan desain penelitian yang bersifat deskriptif-korelatif. Penelitian dilaksanakan di Desa Cibanteng, Kecamatan Ciampea, Kabupaten Bogor. Pemilihan lokasi tersebut didasarkan pada potensi dan kawasan sentra pertanian singkong. Penelitian dilakukan pada bulan Februari hingga Mei 2018. Populasi penelitian adalah seluruh anggota Kelompok Mekar Tani di Desa Cibanteng. Alasan pemilihan kelompok sebagai obyek penelitian disebabkan kelompok merupakan petani pembudidaya tanaman singkong dan menerima layanan penyuluhan. Jumlah populasi dalam penelitian ini adalah 30 orang. Penelitian ini dilakukan secara sensus yaitu menjadikan seluruh anggota populasi penelitian sebagai sampel. Pertimbangan tersebut didasarkan jumlah populasi relatif kecil.

Data yang dikumpulkan dalam penelitian ini terdiri dari data primer dan data sekunder. Data primer adalah data yang diperoleh langsung oleh pengumpul data terhadap petani meliputi umur, pendidikan, pengalaman berusahatani, luas lahan, motivasi, serta sarana dan prasarana produksi. Data sekunder dikumpulkan melalui kunjungan ke instansi terkait, pengambilan data difokuskan pada datadata yang berhubungan dengan usahatani singkong. Instrumen yang digunakan dalam pengumpulan data berupa kuesioner yang berisi daftar-daftar pertanyaan tertutup dan terbuka untuk menjawab tujuan penelitian.

Variabel yang diukur meliputi umur, pendidikan formal, pengalaman berusahatani, luas lahan, motivasi, dukungan sarana dan prasarana, pengetahuan, sikap dan keterampilan. Untuk mengetahui validitas kuesioner maka dilakukan uji validitas dalam bentuk validitas konstruk. Validitas konstruk menunjukkan kesahihan kuesioner melalui pengujian menggunakan beberapa indikator. Kesahihan konstruk diukur dengan menggunakan analisis Korelasi Product Moment. Kesahihan isi menunjukkan bahwa kuesioner tersebut sudah mewakili semua aspek yang dianggap sebagai aspek kerangka konsep.

Keterandalan alat ukur dalam mengukur gejala secara konsisten diuji Desa Cibatok II Kecamatan Cibubungbulang yang memiliki karakteristik relatif sama dengan responden penelitian. Data yang telah dikumpul, ditabulasi, dan dianalisis kemudian dilakukan pengkatagorian sesuai dengan skor yang dihasilkan pada masing-masing hasil pengukurannya. Data karakteristik petani dan kompetensi teknis dianalisis secara deskriptif persentase. Hubungan karakteristik petani dengan kompetensi teknis berusahatani singkong dianalisis dengan mempergunakan uji Kendall W. Uji Korelasi Kendall W adalah uji hipotesis untuk mengetahui hubungan dua variabel. Aplikasi yang digunakan untuk melakukan uji korelasi tersebut menggunakan SPSS versi 21.

\section{Hasil dan Pembahasan}

\subsection{Karakteristik Petani}

Karakteristik petani merupakan sifat-sifat atau ciri-ciri yang dimiliki oleh petani yang melekat pada dirinya. Ciri-ciri yang dimaksud adalah bagian dari diri petani yang terbawa sejak lahir, serta merupakan proses interaksi dengan lingkungan. Karakteristik petani yang dimaksud dalam penelitian ini adalah (1) jenis kelamin (2) umur, (3) pendidikan formal, (4) pengalaman usahatani, (5), luas lahan usahatani, (6) motivasi, dan (7) dukungan sarana prasarana. Hasi penelitian karakteristik petani berdasarkan jenis kelamin di Kelompok Mekar Tani Desa Cibanteng disajikan pada Tabel 1

Tabel 1. Karakteristik Petani Singkong Kelompok Mekar Tani

\begin{tabular}{|c|c|c|}
\hline Kategori & Jumlah & Persentase $(\%)$ \\
\hline \multicolumn{3}{|l|}{ Umur (tahun) } \\
\hline Sangat Muda ( $26-25$ ) & & \\
\hline Muda ( $36-45)$ & 0 & $\begin{array}{c}0 \\
367\end{array}$ \\
\hline Sedang $(46-55)$ & 11 & 36.7 \\
\hline Tua $(56-65)$ & 10 & 0 \\
\hline Pendidikan Formal & 19 & 63.3 \\
\hline Tidak pernah bersekolah & 7 & 23.3 \\
\hline Tamat SD & 14 & 46.7 \\
\hline Tamat SLTP & 9 & 30.0 \\
\hline Tamat SLTA/PT & 0 & 0 \\
\hline \multicolumn{3}{|l|}{ Motivasi } \\
\hline Sangat Rendah $(2-3.49)$ & 0 & 0 \\
\hline Rendah $(3.50-4.99)$ & 0 & 0 \\
\hline Sedang $(5-6.49)$ & 28 & 93.33 \\
\hline Tinggi $(6.5-8)$ & 2 & 6.67 \\
\hline Sarana dan & & \\
\hline \multicolumn{3}{|l|}{ Produksi } \\
\hline Sangat Rendah $(3-5.24)$ & 9 & 30 \\
\hline Rendah $(5.25-7.49)$ & 7 & 23.3 \\
\hline Sedang $(7.50-9.74)$ & 11 & 36.7 \\
\hline Tinggi $(9.75-12)$ & 3 & 10 \\
\hline
\end{tabular}

Sumber: Diolah dari data primer, 2019

Karakteristik petani berdasarkan tingkatan umur petani singkong pada Kelompok Mekar Tani sudah tergolong tua. Umur merupakan suatu faktor yang mempengaruhi kemampuan fisik seseorang dalam berpikir maupun dalam bekerja. Hal tersebut sejalan dengan pernyataan Sukanata et. al (2015) yang dengan melakukan uji coba kuesioner terhadap lima orang petani singkong di 
mengatakan bahwa petani yang lebih muda atau berusia muda akan mempunyai kemampuan bekerja dan beraktifitas yang lebih tinggi dibandigkan dengan petani yang lebih tua. Kecenderungan lain bahwa dalam proses adopsi inovasi baru, petani yang berumur muda akan lebih tanggap bila dibandingkan dengan petani yang berumur lebih tua.

Kelemahan dari petani yang berumur lebih tua, di satu sisi sudah berkurangnya kekuatan fisik, ada sisi lain lagi, dimana petani yang lebih tua mempunyai sifat kehati-hatian dan penuh pertimbangan sehingga dalam proses pengambilan keputusan terkesan lambat. Kelompok petani pada umur muda cenderung lebih produktif dalam menyerap informasi dan memiliki kekuatan fisik yang lebih baik jika dibandingkan dengan petani tua. Susanti et. al (2016) mengemukakan bahwa perkembangan kemampuan berpikir terjadi seiring dengan bertambahnya umur. Kategori umur bukan merupakan faktor psikologis, tetapi apa yang diakibatkan oleh umur adalah faktor psikologis.

Karakteristik petani berdasarkan tingkatan pendidikan formal petani singkong pada Kelompok Mekar Tani mayoritas tamat SD. Pendidikan menunjukkan tingkat intelegensi yang berhubungan dengan daya pikir seseorang. Prilierdi et. al (2015) mendefinisikan pendidikan sebagai usaha untuk menghasilkan perubahan-perubahan pada perilaku manusia. Hal penelitian in sejalan dengan penelitian yang dilakukan oleh Sukanata et. al (2015) yang mengungkapkan walaupun rata-rata petani memiliki tingkat pendidikan formal yang rendah namun jelas terlihat bahwa rata-rata di antara mereka sempat menempuh pendidikan formal artinya semakin banyaknya petani yang berpendidikan akan memudahkan bagi dirinya dan kelompok masyarakat dalam menerima informasi atau pengetahuan yang berasal dari berbagai sumber informasi yang dapat memberikan nilai tambah dalam pengembangan usahataninya.

Karakteristik petani berdasarkan pengalaman berusahatani petani singkong pada Kelompok Mekar Tani masih tergolong rendah. Pengalaman merupakan salah satu cara kepemilikan pengetahuan yang dialami seseorang dalam kurun waktu yang tidak ditentukan. Petani kurang berpengalaman membutuhkan keterampilan untuk pengendalian hama dan penyakit, kewirausahaan dan pemupukan. Karakteristik petani berdasarkan luas lahan petani singkong pada Kelompok Mekar Tani masih tergolong rendah. Lahan merupakan salah satu faktor penting yang menentukan status petani. Jumlah pohon singkong yang ditanam disesuaikan dengan luasan lahan yang dimiliki setiap petani. Lahan berfungsi sebagai tempat diselenggarakan kegiatan produksi pertanian seperti bercocok tanam. Kenyataan di lokasi penelitian menyatakan, bahwa mayoritas petani memiliki sedikit pohon singkong sehingga mengakibatkan produksi singkong yang dihasilkan terbatas karena dipengaruhi luas lahan dari para petani.

Karakteristik petani berdasarkan motivasi petani singkong pada Kelompok Mekar Tani masih tergolong sedang. Motivasi merupakan keadaan internal seseorang yang mendorong orang tersebut untuk melakukan sesuatu. Pendapat tersebut sesuai dengan kondisi di lokasi penelitian menyatakan, bahwa petani memiliki motivasi yang tinggi dalam melakukan kegiatan usahatani singkong. Sukanata et. al (2015) mengungkapkan motivasi yang tinggi dalam beraktivitas disektor pertanian merupakan satu modal besar dari dalam diri petani sendiri untuk menunjang suksesnya berusahatani.

Karakteristik petani berdasarkan sarana dan prasarana petani singkong pada Kelompok Mekar Tani masih tergolong rendah dengan pencapaian 36.7 persen. Ketersediaan sarana produksi mutlak diperlukan agar dapat menjadi pendukung dalam peningkatan produksi. Sarana dan prasarana produksi yang digunakan petani harus mampu mendukung kelancaran usahatani singkong.

\subsection{Pengetahuan, Sikap dan Keterampilan Teknis Usahatani Singkong}

Kompetensi teknis petani dalam berusahatani singkong dapat dijelaskan secara rinci sesuai aspek kompetensi. Mayamsari et al. (2014) mengklasifikasikan kompetensi teknis petani meliputi pengetahuan, sikap dan keterampilan dengan kategori rendah, sedang, tinggi. Pengetahuan tinggi terkait teknis berusahatani singkong memiliki keterkaitan dengan pengalamanan petani dalam berusahatani singkong. Pengetahuan teknis petani berhubungan dengan proses pemahaman, pengolahan informasi tentang teknis usahatani singkong. Hasil penelitian ini sesuai dengan penelitian Bahua dan Limonu (2015) yang mengemukakan bahwa pengetahuan merupakan salah satu aspek kompetensi yang harus dikuasai petani.

Sikap petani yang tergolong sedang dilihat dari rangkaian tindakan petan dengan melakukan teknis berusahatani singkong mulai pengolahan lahan, pemilihan bibit, pemupukan, pengendalian hama serta panen dan pascapanen. Aspek kompetensi petani pada keterampilan justru tergolong rendah. Sikap petani berkaitan dengan minat, motivasi dan emosi petani dalam berusahatan singkong. Narti (2015) menyatakan meskipun dimensi efek penegetahuan, sikap dan keterampilan berhubungan satu sama lain, namun ketiganya juga independen satu sama lain. Kompetensi teknis petani dalam berusahatani singkong berdasarkan aspek pengetahuan, sikap dan keterampilan disajikan pada Tabel 2 .

Keterampilan tergolong rendah. Pengetahuan dan sikap petani yang ternyata tidak sejalan dengan keterampilan petani yang masih tergolong rendah. Pada pengolahan lahan petani sudah mengetahui bahwa pengolahan lahan mesti harus dilakukan sebelum penanaman singkong, akan tetapi petani masih beranggapan tanpa pengolahan lahan pun singkong akan tetap bisa tumbuh dengan baik. Bahua dan Limonu (2015) menyatakan keterampilan petani dapat berhasil jika ditunjang oleh pengetahuan berusahatani yang dapat berimplikasi pada peningkatan produksi pertanian. Keterampilan petani terbentuk melalui proses berkelanjutan. Kompetensi merupakan kemampuan dan rasa tanggung jawab petani secara teknis dalam mengelola usahatani singkong. Hasil penelitian kompetensi teknis yang dilakukan terhadap petani singkong di Kelompok Mekar Tani Desa Cibanteng dapat dilihat pada Tabel 3.

Tabel 2. Kompetensi Teknis Petani Berdasarkan Pengetahuan, Sikap dan Keterampilan

\begin{tabular}{llcc}
\hline Aspek Kompetensi & \multicolumn{1}{c}{ Kategori } & Jumlah & Persentase (\%) \\
\hline Pengetahuan & Sangat rendah & 0 & 0 \\
& Rendah & 0 & 0 \\
& Sedang & 6 & 20 \\
\multirow{5}{*}{ Sikap } & Tinggi & 24 & 80 \\
& Sangat rendah & 0 & 0 \\
& Rendah & 12 & 40 \\
\multirow{3}{*}{ Keterampilan } & Sedang & 18 & 60 \\
& Tinggi & 0 & 0 \\
& Sangat rendah & 11 & 36,67 \\
& Rendah & 18 & 60 \\
& Sedang & 1 & 3,33 \\
& Tinggi & 0 & 0 \\
\hline
\end{tabular}

Sumber: Diolah dari data primer, 2019

Tabel 3 Tingkat Kompetensi Teknis Petani Singkong

\begin{tabular}{ccc}
\hline Kategori & Jumlah & Jumlah $(\%)$ \\
\hline Sangat rendah & 0 & 0 \\
Rendah & 19 & 63,34 \\
Sedang & 10 & 33.33 \\
Tinggi & 1 & 3,33 \\
\hline
\end{tabular}

Sumber: Diolah dari data primer, 2019

Kompetensi teknis petani singkong pada Kelompok Mekar Tani masih kategori rendah. Kompetensi teknis petani tersebut meliputi pemilihan bibit, penanaman, pemupukan, pengendalian hama, dan panen dan pascapanen. Petani singkong dalam memilih variates benih singkong yang hendak ditanam belum memperhatikan kualitas dari benih atau bibit singkong. Dosis pemupukan dilakukan melalui perkiraan sendiri oleh petani. Pupuk yang biasa digunakan hanya Urea dan NPK. Pemupukan 2 kali dilakukan sejak penanaman hingga panen. Pengendalian hama berupa penyiangan hanya satu kali dilakukan oleh petani selama musim tanam.

Petani memanen singkong dalam waktu rata 10-12 bulan, hal ini berbeda dengan tanaman singkong varietas unggul yang sudah bisa dipanen dalam waktu 7-9 bulan. Pada umumnya petani belum melakukan pengolahan singkong menjadi produk olahan yang lebih bernilai ekonomis. Kompetensi teknis petani tergolong tinggi dan sangat tinggi hal ini dipengaruhi pengetahuan, sikap dan keterampilan petani dalam mulai dari pemilihan bibit varietas unggul. Petani yang menanam singkong varietas unggul mengaku bisa mendapatkan produksi 15 ton/ha

\subsection{Hubungan Karakteristik Petani dengan Kompetensi Teknis}

Hasil penelitian menunjukkan tiga karakteristik petani yang memiliki hubungan nyata dengan kompetensi teknis dalam berusahatani singkong. Koefisien korelasi Kendall $W$ menunjukkan hubungan nyata antara karakteristik pengalaman berusahatani, luas lahan, serta sarana dan prasarana produksi dengan kompetensi teknis. Hasil penelitian ini berbeda dengan penelitian Manyamsari dan Mujiburrahmad (2014) yang menunjukkan Karakteristik yang berhubungan secara signifikan dengan kompetensi petani lahan sempit meliputi pendidikan formal, luas lahan dan pemanfaatan media informasi. Karakteristik yang tidak berhubungan secara signifikan meliputi umur, pelatihan, pengalaman berusaha tani. Umur dengan kompetensi petani tidak memliki hubungan nyata. Analisis hubungan karakteristik dengan Kompetensi disajikan pada Tabel 4.

Tabel 4 Hubungan Karakteristik Petani dengan Kompetensi Teknis

\begin{tabular}{lc}
\hline Faktor Korelasi & Nilai Korelasi Kendall $W$ \\
\hline Umur & -.248 \\
Pendidikan & -.112 \\
Pengalaman berusahatani & $.466^{* *}$ \\
Motivasi & .325 \\
Luas Lahan & $.507^{* *}$ \\
Sarana dan Prasarana Produksi & $.355^{*}$ \\
\hline
\end{tabular}

Sumber: Diolah dari data primer, 2019

Keterangan: ** Signifikan pada level $0.01 *$ Signifikan pada level 0.05

Hasil penelitian menunjukkan petani yang berada dalam umur muda (produktif) ternyata tidak memiliki hubungan secara nyata dengan kompetens teknis usahatani singkong. Pertambahan umur bisa menjadikan petani semakin dewasa baik secara psikis, psikologis dan sosiologis, namun apabila tidak diikuti oleh proses belajar, maka petani tidak akan memiliki kompetensi yang lebih baik

Pendidikan dengan kompetensi tidak memiliki hubungan nyata. Tingkat pendidikan petani singkong tidak mencerminkan hubungan dengan kompetens teknis. Petani yang berpendidikan rendah mengangap bidang kompetensi yang paling penting adalah pemilihan bibit, penanaman, pemupukan, penyiangan dan panen. Hasil penelitian berbeda dengan penelitian Bahua dan Limonua (2015) 
menunjukkan pendidikan petani memiliki hubungan nyata dengan kompetensi teknis dalam berusahatani. Penelitian Manyamsari dan Mujiburrahmad (2014) juga menunjukkan pendidikan formal berhubungan secara signifikan dengan bidang kompetensi petani meliputi pemasaran hasil usaha, panen dan penanganan pascapanen. Pengalaman petani dalam berusahatani singkong memiliki hubungan nyata dengan kompetensi teknis. Petani yang memiliki pengalaman berusahatani tinggi mengangap kompetensi paling penting meliputi pengolahan lahan, pemilihan bibit, pengendalian hama, pemupukan dan penanganan pascapanen.

Hasil penelitian sejalan dengan penelitian Bahua dan Limonu (2015) menujukkan petani dengan pengalaman berusahatani rendah menganggap kompetensi paling penting adalah pengolahan lahan, penanaman dan pemanenan. Petani dengan pengalaman berusahatani tinggi menganggap kompetensi paling penting adalah pengolahan lahan, pemilihan bibit, pengendalian hama dan panen. Hasil penelitian Sukanata et. al (2015) juga menunjukkan pengalaman berusahatani berhubungan secara nyata dengan pengetahuan, sikap dan keterampilan petani dalam berusahatani. Motivasi petani dalam berusahatani singkong tidak memiliki hubungan nyata dengan kompetensi teknis.

Tingkat motivasi petani sedang dan tinggi pada hasil penelitian namun tidak memiliki hubungan nyata dengan tingkat kompetensi teknis. Petani memiliki motivasi sedang dan tinggi menganggap bidang kompetensi penting dalam berusahatani singkong meliputi penanaman, pemupukan, pengendalian hama penyakit dan panen. Luas lahan memiliki hubungan yang nyata dengan kompetensi teknis usahatani singkong. Hal ini berarti semakin luas semakin luas lahan usahatani singkong maka semakin tinggi kompetensi petani dalam mengelola usahataninya. Dengan demikian petani yang memiliki lahan yang lebih luas akan memberikan pengaruh terhadap usahatani yang dilakukan, sehingga cenderung meningkatkan kompetensi dalam berusahatani untuk menghasilkan produksi total yang tinggi.

Petani singkong yang memiliki luas lahan kategori sempit menganggap bidang kompetensi yang paling penting dalam melaksanakan kegiatan usahatani singkong meliputi penanaman, penyiangan dan pemanenan. Bidang lain yang dianggap kurang penting dalam usahatani singkong seperti pengolahan lahan, pemupukan dan penanganan pascapanen. Hasil penelitian Narti (2015) menunjukkan kompetensi yang perlu dikuasai oleh petani lahan sempit meliputi pengendalian hama dan penyakit serta penggunaan teknologi secara efisien. Hasil penelitian menunjukkan petani singkong yang memiliki lahan sangat luas menganggap bidang kompetensi yang paling penting dalam melaksanakan kegiatan usahatani singkong meliputi pengolahan lahan, pemilihan bibit, pemupukan, dan penggunaan teknologi.

Hasil penelitian ini sejalan dengan hasil penelitian Narti (2015) yang menyatakan petani dengan lahan sangat luas menganggap bidang kompetensi paling penting dalam berusahatani meliputi pemilihan bibit unggul dan pemanfaatan inovasi teknologi. Kompetensi petani menunjukkan petani dengan lahan sangat luas petani menganggap bidang kompetensi yang paling penting meliputi penanaman dan pemeliharaan, pemupukan dan pengendalian hama penyakit, dan panen dan pascapanen. Hasil penelitian Manyamsari dan Mujiburrahmad (2014) tentang hubungan karakteristik petani dengan kompetensi menyatakan petani yang lahannya luas dan sedang lebih mementingkan bidang kompetensi kombinasi cabang usaha, sedangkan petani yang lahannya sempit lebih mementingkan jiwa kewirausahaan.

Dukungan sarana dan prasarana produksi memiliki hubungan nyata dengan kompetensi teknis petani dalam berusahatani singkong. Sarana dan prasarana produksi sangat dibutuhkan petani dalam melakukan aktivitas pertanian, agar menjadi pendukung dalam peningkatan produksi. Sarana produksi yang mendukung usahatani singkong di Desa Cibanteng tersedianya bibit, pupuk, obat-obatan, dan peralatan pertanian lainnya. Meskipun peralatan yang petani gunakan umumnya masih sederhana. Prasarana pertanian petani dalam berusahatani singkong tersedia melalui pedagang-pedagang sarana produksi di daerah sekitar tempat tinggal petani, meski jumlahnya sangat terbatas.

\section{Simpulan}

Berdasarkan hasil penelitian dan pembahasan dapat dikemukakan simpulan sebagai berikut: 1).Petani singkong dalam penelitian ini sebanyak 63.30 persen telah berumur tua, 53.30 persen berpendidikan formal rendah (SD), 60 persen petani memiliki pengalaman berusahatani singkong rendah (1-5 tahun), 80 persen petani memiliki luas lahan sempit $\left(1000 \mathrm{~m}^{2}-5000 \mathrm{~m}^{2}\right), 93.33$ persen petani memiliki motivasi tinggi dalam berusahatani, dan 36.67 persen dukungan sarana dan prasarana produksi tinggi. 2). Kompetensi teknis petani 63.34 persen (rendah) dalam berusahatani singkong. Pengetahuan petani 80 persen tinggi dalam berusahatani. Sikap petani 60 persen (tinggi) dalam berusahatani singkong. Keterampilan petani 60 persen (rendah) dalam berusahatani singkong. 3). Karakteristik petani singkong yang menunjukkan hubungan nyata dengan kompetensi teknis dalam berusahatani singkong meliputi pengalaman berusahatani, luas lahan dan dukungan sarana prasarana produksi.

\section{Pustaka}

Bakhtiar A, Amanah S, Fatchiya A. 2017. Kompetensi Pembudidaya Ikan Lele Dalam Mengelola Usaha di Muncar Banyuwangi Jawa Timur. Jurnal Penyuluhan 13(2): 222-230.
Bahua MI, Limonu M. 2015. Hubungan Karakteristik Petani dengan Kompetensi Usahatani Jagung. Gorontalo di Tiga Kecamatan di Kabupaten Pohuwato. Lembaga Penelitian. Gorontalo: Universitas Negeri Gorontalo.

Dewi IN, Awang SA, Andayani W, Suryanto P. 2018. Karakteristik Petani dan Kontribusi Hutan Kemasyarakatan (HKm) Terhadap Pendapatan Petani di Kulon Progo. Jurnal Ilmu Kehutanan 12 (1): 86-98.

Leasa WB, Amanah S, Fatchiya A. 2018. Kapasitas Pengolah Ubi Kayu "Enbal" dan Pengaruhnya terhadap Keberlanjutan Usaha di Maluku Tenggara. Jurnal Penyuluhan 14 (1): 11-26.

Manyamsari I, Mujiburrahmad. 2014. Karakteristik Petani dan Hubungannya dengan Kompetensi Petani Lahan Sempit. Agrisep Vol 15 (2). doi: agrisep/article/view/2099.

Narti S. 2015. Hubungan Karakteristik Petani Dengan Efektivitas Komunikasi Penyuluhan Pertanian Dalam Program SL-PTT (Kasus Kelompok Tani Di Kecamatan Kerkap Kabupaten Bengkulu Utara). Jurnal Profesional 2 (2): 40-52.

Prilierdi A, Abubakar R, Iskandar S. 2015. Hubungan Karakteristik Petan Terhadap Pendapatan Usahatani Semangka (Citrullus Vulgaris) Di Desa Sugih Waras Kecamatan Muara Sugihan Kabupaten Banyuasin. SOCIETA 4 (1): $27-32$.

Sukanata I, Dukat, Yuniati A. 2015. Hubungan Karakteristik dan Motivasi Petani Dengan Kinerja Kelompok Tani (Studi Kasus Desa Cisaat Kecamatan Dukupuntang). Jurnal Agrijati 28 (1): 17-34.

Susanti D, Nurul L, Widayat T. 2016. Pengaruh Umur Petani, Tingkat Pendidikan dan Luas Lahan Terhadap Hasil Produksi Tanaman Sembung. Jurnal Tumbuhan Obat Indonesia 9 (2): 75-82. 